\title{
REGULASI PENYELENGGARAAN JAMINAN PRODUK HALAL DI INDONESIA PERSPEKTIF STATUTE APPROACH
}

\author{
Muhammad Aziz
}

Sekolah Tinggi Agama Islam Al-Hikmah Tuban, Indonesia

E-mail: mohaziv@yahoo.com

Ahmad Rofiq
Universitas Islam Negeri Walisongo Semarang, Indonesia
E-mail: arofiq@gmail.com

Abdul Ghofur

Universitas Islam Negeri Walisongo Semarang, Indonesia E-mail: aghofur2009@walisongo.ac.id

\begin{abstract}
This research is focused on the regulation of implementing guarantee for halal products in Indonesia and crucial issues related to them. This research is normative juridical research using a statute approach. The conclusions of this study include; first, there are several crucial issues and topics relating to the implementation of guarantee of halal products in Indonesia, namely halal certification, mandatory and voluntary in halal certification, criminal provisions, and halal product guarantee management institutions. Second, the regulation of halal product guarantees when viewed from the Statute Approach can be analyzed using three legal principles: (1) lex superior derogat legi inferiori concludes that all rules for guaranteeing lower halal products are replaced by the higher ones; (2) lex specialis derogat legi generali confirms that the JPH Law is a specific regulation that regulates the guarantee of halal products; and (3) lex posterior derogat legi priori requires that the rules for guaranteeing halal products as contained in the JPH Law replace the guarantee rules for halal products that existed in the previous period.
\end{abstract}

Keywords: Regulations; halal product guarantees; mandatory and valountary certification. 


\section{Pendahuluan}

Pada 2014, penyelenggaraan jaminan produk halal di Indonesia menemukan momentumnya. Hal tersebut ditandai dengan pengesahan Undang-Undang (UU) No. 33 Tahun 2014 tentang Jaminan Produk Halal (JPH) oleh DPR. ${ }^{1}$ UU JPH telah melalui perjalanan yang cukup panjang, dari periode DPR RI 2004-2009 hingga periode 2014-2019. Perjalanan panjang produk UU ini menunjukkan adanya vested interest ${ }^{2}$ baik dari kelompok agama, politisi, maupun pelaku bisnis. ${ }^{3}$ Perdebatan di kalangan politisi DPR tentang UU ini pada dasarnya lebih bersifat formalistisprosedural, bukan pada aspek sosial kebutuhan masyarakat dalam hal perlindungan produk yang harus dijamin oleh negara. ${ }^{4}$ Namun demikian, periode tersebut bukanlah awal mula regulasi jaminan produk halal ada di Indonesia.

Secara historis, jejak regulasi jaminan produk halal di Indonesia dimulai sejak masa awal pemerintahan Orde Baru (Orba), ditandai dengan munculnya Surat Keputusan Menteri Kesehatan (SK Menkes) No. 280/Menkes/Per/XI/1976 tanggal 10 November 1976 tentang Ketentuan Peredaran dan Penandaan pada Makanan yang Mengandung Bahan Berasal dari Babi. Setelah itu, regulasi produk halal di Indonesia tersebar pada beberapa Peraturan Menteri (Permen), Peraturan Pemerintah (PP), dan UU. Sementara secara periodik, dari periode kemunculannya sampai disahkannya $\mathrm{UU} \mathrm{JPH}$, instrumen regulasi yang digunakan hampir tidak sama antara satu periode dengan lainnya. Ada yang menggunakan bentuk Peraturan Menteri Kesehatan (Permenkes), Peraturan Bersama Menteri Agama (Menag) dan Menteri Kesehatan (Menkes),

\footnotetext{
1 Asep Saepudin Jahar dan Thalhah, "Dinamika Sosial Politik Pembentukan Undang-Undang Jaminan Produk Halal", Al-Ibkam: Jurnal Hukum dan Pranata Sosial, Vol. 12, No. 2 (2017), 386. Bandingkan dengan laporan Kompas.com, "Debat Sengit RUU Produk Halal terkait Siapa yang Harus Menangani Sertifikasi”, 27 Februari 2014. Diakses pada 25 April 2019.

${ }^{2} V$ ested interest berarti adanya kepentingan golongan yang telah tertanam dengan kuat sekali. Golongan ini sangat sukar sekali melepas kedudukannya, kekuasaannya, atau pengaruhnya. Golongan ini, salah satu contohnya adalah Majelis Ulama Indonesia (MUI).

3 Lihat laporan Detik.com, "RUU Jaminan Halal Ditarget Selesai dibabas Februari 2013", 23 Januari 2013, https://news.detik.com/berita/2150155/ruujaminan-produk-halal-ditarget-selesai-dibahas-februari-2013. Diakses 10 Mei 2019.

"Jahar dan Thalhah, "Dinamika Sosial Politik", 387.
} 
Keputusan Menteri Agama (Kepmenang), PP, dan ada juga yang berbentuk UU. ${ }^{5}$ Namun demikian, semuanya berada dalam rangka penyelenggaraan jaminan produk halal di Indonesia.

Semua bentuk regulasi dan peraturan yang berkaitan dengan jaminan produk halal di Indonesia merupakan bagian dari proses pembentukan hukum dan merupakan dasar legalitas bagi seluruh elemen negara dalam menyelenggarakan dan mengelola negara. Dalam negara demokrasi seperti Indonesia, regulasi dan perundang-undangan dibuat oleh rakyat melalui wakil-wakilnya di lembaga legislatif. Melalui lembaga legislatif inilah, aspirasi rakyat diagregasi untuk kemudian dituangkan dalam UU yang berlaku mengikat. ${ }^{6}$

Menyadari perkembangan produk halal yang signifikan, artikel ini akan mengkaji regulasi jaminan produk halal di Indonesia mulai masa Orba hingga pascareformasi yang ditandai dengan lahirnya UU No. 33 Tahun 2014 tentang JPH yang cukup revolusioner. Kajian ini terutama difokuskan pada isu-isu krusial yang berkaitan dengan penyelenggaraan jaminan produk halal, berikut regulasinya terkait sertifikasi dan labelisasi halal yang pernah ada dan berlaku di Indonesia.

Untuk memberikan analisis yang tajam, artikel ini melakukan perbandingan antara satu peraturan dengan peraturan lain yang ada di Indonesia. Perbandingan ini meliputi penyajian persamaan dan perbedaan dari tiap-tiap peraturan perudangan-undangan untuk kemudian dilihat dalam perspektif statute approach (pendekatan perundang-undangan) Peter Mahmud Marzuki. ${ }^{7}$ Adapun metode yang digunakan dalam kajian ini adalah yuridis-normatif, ${ }^{8}$ yang

\footnotetext{
${ }^{5}$ Untuk kajian lebih komprehensif, lihat Azmi Siradjuddin, "Regulasi Makanan Halal di Indonesia", Jurnal Tapis, Vol. 13, No. 01 (2013).

6 Abdul Ghofur, "Pergumulan Politik Legislasi Undang-Undang Nomor 21 Tahun 2018 tentang Perbankan Syariah” (Disertasi--IAIN Walisongo Semarang, 2013), 8-9.

${ }^{7}$ Selain dinilai tepat untuk mendudukkan setiap aturan hukum secara sejajar dan seimbang, teori ini juga dipilih karena objek penelitian akan difokuskan pada suatu aturan hukum yang menjadi tema sentral dalam artikel ini. Johni Ibrahim, Teori \& Metodologi Penelitian Hukum Normatif (Malang: Banyumedia Publishing, 2006), 302.

8 Penelitian hukum normatif bermakna penelitian yang difokuskan untuk mengkaji penerapan kaidah-kaidah atau norma-norma dalam hukum positif. Lihat ibid., 295. Bandingkan dengan penjelasan Ronny Hanitijo Soemitro, Metodologi Penelitian Hukum dan Jurimetri (Jakarta: Ghalia Indonesia, 1988), 13-14.
} 
meliputi inventarisasi hukum positif, penelitian terhadap asas-asas hukum dan hukum in concreto (pada peristiwa hukum tertentu), sistematik hukum, sejarah hukum, dan perbandingan hukum. ${ }^{9}$ Data yang digunakan merupakan data sekunder, berupa bahan-bahan hukum primer, sekunder, dan tersier. ${ }^{10}$ Kajian ini bersifat deskriptif-analitis, yaitu membuat pencarian secara sistematis mengenai fakta-fakta, ${ }^{11}$ termasuk di dalamnya mendeskripsikan dan menganalisis peraturan-peraturan yang berlaku di Indonesia, ${ }^{12}$ khususnya tentang produk halal.

\section{Jaminan Produk Halal: ${ }^{13}$ Sertifikasi ${ }^{14}$ dan Labelisasi ${ }^{15}$}

Regulasi sertifikasi halal sebuah produk makanan, obat-obatan, dan kosmetik merupakan bagian dari perlindungan terhadap konsumen, khususnya konsumen Muslim. ${ }^{16}$ Islam memerintahkan setiap penganutnya untuk mengkonsumsi produk, baik berupa

\footnotetext{
9 Ibid., 9-10.

10 Soerjono Soekanto et al., Penelitian Hukum Normatif: Suatu Tinjauan Singkat (Jakarta: Rajawali, 2006), 13-14.

${ }^{11}$ Soemitro, Metodologi Penelitian, 22.

12 Sumadi, Metode Penelitian (Jakarta: Rajawali 1988), 19.

13 Kotler dan Armstrong mendefenisikan produk adalah segala sesuatu yang dapat ditawarkan ke pasar untuk perhatian, akuisisi, penggunaan, dan konsumsi yang dapat memuaskan keinginan atau kebutuhan. Produk mencakup barang fisik, jasa, orang, organisasi, gagasan, atau gabungan dari semua itu. Nembah F. Hartimbul Ginting, Manajemen Pemasaran (Bandung: Yrama Widya, 2011), 90.

14 Sertifikasi halal adalah proses pengakuan kehalalan suatu produk yang dikeluarkan oleh Badan Penyelenggara Jaminan Produk Halal (BPJPH) berdasarkan fatwa tertulis yang dikeluarkan oleh MUI. Panji Adam, "Kedudukan Sertifikasi Halal dalam Sistem Hukum Nasional sebagai Upaya Perlindungan Konsumen dalam Hukum Islam", Jurnal Amwaluna, Vol. 1, No. 1 (2017), 150; Mutimmatul Faidah, "Sertifikasi Halal di Indonesia; Dari Civil Society Menuju Relasi Kuasa Antara Negara dan Agama”, Islamica: Jurnal Studi Keislaman, Vol. 11, No. 2 (2017), 455.

15 Labelisasi halal adalah pencantuman tulisan atau pernyataan halal pada kemasan produk untuk menunjukkan bahwa produk yang dimaksud berstatus halal. Lihat KN Sofyan Hasan, "Kepastian Hukum Sertfikisai dan Labelisasi Halal Produk Pangan", Jurnal Dinamika Hukum, Vol. 14, No. 2 (2014), 231. Sertifikat halal dan labelisasi halal merupakan dua kegiatan yang berbeda tetapi mempunyai keterkaitan satu sama lain.

${ }^{16}$ Hal ini sesuai dengan spirit UU No. 8 Tahun 1999 tentang Perlindungan Konsumen. Untuk elaborasi lebih jauh, lihat Teti Indrawati Purnamasari, "Pengaturan Bentuk-Bentuk Perlindungan Konsumen dalam Penyelenggaraan Jaminan Produk Halal dan Tayib di Indonesia" (Disertasi--Universitas Gadjah Mada Yogyakarta, 2015), 674-679.
} 
barang atau jasa, dari sesuatu atau bahan-bahan yang baik, suci, dan bersih (al-Baqarah [2]: 172), karena hal tersebut senantiasa terkait dengan hukum halal dan haram.

Perlindungan atas konsumen merupakan hal yang sangat penting dalam hukum Islam. ${ }^{17}$ Islam melihat hal tersebut bukan sebagai hubungan keperdataan semata, tetapi juga menyangkut kepentingan publik secara luas, bahkan menyangkut hubungan antara manusia dengan Allah. Dalam konteks Indonesia, upaya perlindungan konsumen Muslim atas produk barang dan jasa menjadi penting setidaknya menurut dua hal; (1) konsumen Indonesia mayoritas beragama Islam, yang harus mendapat perlindungan atau jaminan atas segala jenis produk barang dan jasa yang sesuai dengan kaidah-kaidah hukum Islam; dan (2) Pemerintah Indonesia sudah melakukan upaya aktif untuk melindungi konsumen yang mayoritas beragama Islam.

Dalam UU No. 8 Tahun 1999 pasal 4 (a) disebutkan bahwa hak konsumen adalah hak atas kenyamanan, keamanan, dan keselamatan dalam mengkonsumsi barang dan atau jasa. ${ }^{18}$ Pasal ini menunjukkan bahwa setiap konsumen, dalam hal ini umat Muslim, berhak untuk mendapatkan barang yang nyaman (halal) untuk dikonsumsi. Sementara itu, sebelum UU No. 33 Tahun 2014 disahkan, kewajiban produsen untuk melakukan sertifikasi halal telah ada berdasarkan UU No. 7 Tahun 1996 dan UU No. 8 Tahun 1999. Sertifikasi halal tidak hanya menguntungkan konsumen, tetapi juga produsen. ${ }^{19}$ Produk halal meningkatkan kepercayaan dan loyalitas konsumen, baik Muslim maupun non-Muslim. ${ }^{20}$

Jaminan produk halal perlu diinformasikan kepada masyarakat berdasarkan pranata hukum yang mapan, sentral, humanis, progresif, akomodatif, dan tidak diskriminatif sesuai UU No. 33

\footnotetext{
${ }^{17}$ Ibid.

${ }^{18}$ UU No. 8 Tahun 1999 tentang Perlindungan Konsumen.

${ }_{19}$ Sertifikasi dan labelisasi halal bertujuan untuk memberikan kepastian hukum dan perlindungan terhadap konsumen, serta meningkatkan daya saing produk dalam negeri dalam meningkatkan pendapatan nasional. Teti Indrawati Purnamasari, "Sertifikasi dan Labelisasi Produk Pangan Halal dalam Rangka Perlindungan Konsumen Muslim di Indonesia", Jurnal Istinbath, Vol. 1, No. 1 (2005), 48.

${ }^{20}$ Ramlan dan Nahrowi, "Sertifikasi Halal sebagai Penerapan Etika Bisnis Islami dalam Upaya Perlindungan bagi Konsumen Muslim”, Abkam: Jurnal Ilmu Syariah, Vol. 14, No. 1 (2014), 147.
} 
Tahun $2014,{ }^{21}$ yang memperkuat dan mengatur berbagai regulasi halal. Jaminan produk halal ini mencakup berbagai aspek, mulai obat-obatan, makanan, kosmetik, kimiawi, biologi, rekayasa genetik, dan barang yang digunakan dan dimanfaatkan oleh masyarakat. Proses produk halal sebagai rangkaian kegiatan untuk menjamin kehalalan produk mencakup penyediaan bahan, pengolahan, penyimpanan, pengemasan, pendistribusian, penjualan, dan penyajian produk. ${ }^{22}$

Tujuan UU JPH adalah untuk menjamin setiap pemeluk agama beribadah dan menjalankan ajaran agamanya; memberikan pelindungan dan jaminan tentang kehalalan produk yang dikonsumsi dan digunakan masyarakat sesuai dengan asas pelindungan, keadilan, kepastian hukum, akuntabilitas dan transparansi, efektivitas dan efisiensi, serta profesionalitas. ${ }^{23}$ Selain itu, penyelenggaraan sistem produk halal bertujuan memberikan kenyamanan, keamanan, keselamatan, dan kepastian ketersediaan produk halal bagi masyarakat, serta meningkatkan nilai tambah bagi pelaku usaha untuk memproduksi dan menjual produk halal.

Pelaku usaha yang mengajukan permohonan sertifikat halal wajib (1) memberikan informasi secara benar, jelas, dan jujur; (2) memisahkan lokasi, tempat dan alat penyembelihan, pengolahan, penyimpanan, pengemasan, pendistribusian, penjualan, dan penyajian antara produk halal dan tidak halal; (3) memiliki penyelia halal; dan (4) melaporkan perubahan komposisi bahan kepada Badan Penyelenggara Jaminan Produk Halal (BPJPH). Sementara itu, bagi pelaku usaha yang telah memperoleh sertifikat halal memiliki kewajiban (1) mencantumkan label halal terhadap produk yang telah bersertifikat halal; (2) menjaga kehalalan produk tersebut; (3) memisahkan lokasi, tempat penyembelihan, alat pengolahan, penyimpanan, pengemasan, pendistribusian, penjualan, dan penyajian antara produk halal dan tidak halal; (4) memperbarui sertifikat halal jika masa berlakunya berakhir; dan (5) melaporkan perubahan komposisi bahan kepada BPJPH. ${ }^{24}$

21 KN Sofyan Hasan, Sertifikasi Halal dalam Hukum Positif: Regulasi dan Implementasinya di Indonesia (Yogyakarta: Aswaja Pressindo, 2014), 45.

${ }^{22}$ UU No. 33 Tahun 2014 tentang JPH.

${ }^{23}$ Ibid.

${ }^{24}$ Ibid. 
Pembiayaan sertifikasi halal dibebankan kepada pelaku usaha yang mengajukan permohonan sertifikat halal. Untuk memperlancar penyelanggaraan jaminan produk halal, regulasi ini memberikan peran bagi pihak lain, seperti pemerintah, untuk memfasilitasi biaya sertifikasi halal bagi pelaku usaha mikro dan kecil melalui Anggaran Pendapatan dan Belanja Negara (APBN) ${ }^{25}$

\section{Perspektif Statute Approach}

Pendekatan perundang-undangan dilakukan dengan menelaah semua UU dan regulasi yang bersangkut-paut dengan isu hukum yang sedang diteliti. Bagi penelitian kegiatan praktis, pendekatan undang-undang ini akan membuka temuan ada-tidaknya konsistensi dan kesesuaian antara satu UU dengan UU lainnya; antara UU dan UUD; antar regulasi lain dan UU. Sementara bagi penelitian kegiatan akademis, dengan mencari ratio legis dan dasar ontologis lahirnya UU, akan bisa ditangkap kandungan filosofi di belakang sebuah UU, sekaligus bisa disimpulkan ada-tidaknya benturan filosofis antara UU dengan isu yang dihadapi. ${ }^{26}$

Pasal 1 angka 2 UU No. 10 Tahun 2004 menyatakan bahwa peraturan perundang-undangan adalah peraturan tertulis yang dibentuk oleh lembaga negara atau pejabat yang berwenang dan mengikat secara umum. Pengertian ini menjelaskan bahwa yang dimaksud sebagai statute adalah legislasi dan regulasi. Pendekatan peraturan perundang-undangan adalah pendekatan dengan menggunakan legislasi dan regulasi. Produk yang merupakan decree, yaitu suatu keputusan yang diterbitkan oleh pejabat administrasi yang bersifat konkret dan khusus, misalnya Keputusan Presiden, Menteri, Bupati, atau keputusan suatu badan tertentu, tidak dapat digunakan dalam pendekatan perundang-undangan.

Pemahaman ini kemudian mempunyai arti penting dalam memahami beberapa asas dalam perundang-undangan. ${ }^{27}$ Pertama, lex superior derogat legi inferiori (peraturan yang secara hirarkis lebih tinggi mengenyampingkan peraturan yang lebih rendah). Menurut asas ini, apabila terjadi pertentangan peraturan perundangan-

\footnotetext{
${ }^{25}$ Asep Syarifuddin Hidayat dan Mustolih Siradj, "Sertifikasi Halal dan Sertifikasi Non Halal pada Produk Pangan Industri”, Ahkam: Jurnal Ilmu Syariah, Vol. 15, No. 2 (2015), 207.

26 Peter Mahmud Marzuki, Penelitian Hukum (Jakarta: Prenada Media Group, 2010), 93-94.

${ }^{27}$ Ibid., 98-99.
} 
undangan antara yang secara hirarkis lebih rendah dengan yang lebih tinggi, maka yang lebih rendah tersebut harus disisihkan. Kedua, lex specialis derogat legi generali (peraturan yang khusus dapat mengganti peraturan yang umum). Asas ini merujuk kepada dua peraturan perundang-undangan yang secara hirarkis mempunyai kedudukan yang sama, akan tetapi ruang lingkup materi muatannya berbeda; yang satu merupakan pengaturan khusus dari yang lain. Ketiga, lex posterior derogat legi priori (peraturan perundang-undangan yang belakangan menyisihkan yang terdahulu). Asas ini berkaitan dengan dua peraturan perundang-undangan yang mengatur masalah yang sama, misalnya UU No. 14 Tahun 1970 tentang Ketentuan-Ketentuan Pokok Kekuasaaan Kehakiman dan UU No. 4 Tahun 2004 tentang kekuasaan kehakiman. Seperti asas lex specialis derogat legi generali, penggunaan asas ini mensyaratkan kesamaan tingkatan hirarki dua peraturan perundang-undangan yang diperhadapkan.

\section{Isu-Isu Krusial dalam Regulasi Jaminan Produk Halal di Indonesia}

1. Sertifikasi dan labelisasi halal

Upaya sertifikasi dan labelisasi halal telah ditemukan jejaknya dalam regulasi yang dibuat pada masa bergulirnya pemerintahan Orba. Adapun regulasi yang dianggap paling awal yaitu Permenkes RI No. 280/Menkes/Per/XI/1976 tentang Ketentuan Peredaran dan Penandaan pada Makanan yang Mengandung Bahan Berasal dari Babi. ${ }^{28}$ Setelah regulasi pertama tersebut, regulasi produk halal, termasuk sertifikasi dan labelisasi, ditemukan dan tersebar pada beberapa Permen, PP, dan UU, yang akan disebutkan secara lebih rinci berikut ini.

Keputusan Bersama Menkes dan Menag RI No. 427/Menkes/VIII/1985 dan No. 68 Tahun 1985 tentang Pencantuman Tulisan "Halal" pada Label Makanan; dan Surat Keputusan Bersama (SKB) Menag dan Menkes No. 472/Menkes/SKB/VIII/1985 dan No. 68/1985 tentang Pengaturan Tulisan "Halal” pada Label Makanan.

\footnotetext{
${ }^{28}$ Regulasi ini mengharuskan semua makanan dan minuman yang mengandung unsur babi diberi label tulisan "mengandung babi" dan diberi gambar seekor babi utuh berwarna merah di atas dasar putih. Hendri F. Isnaeni, "Sejarah Awal Label Halal", 14 October 2016, dalam https://historia.id/agama/articles/ sejarah-awal-label-halal-PNRMZ. Diakses pada 24 Oktober 2018.
} 
Instruksi Presiden (Inpres) No. 2 Tahun 1991 tentang Peningkatan Pembinaan dan Pengawasan Produksi dan Peredaran Makanan Olahan yang terbit pada 12 Juni 1991, menyebutkan bahwa masyarakat perlu dilindungi dari produk dan peredaran makanan yang tidak memenuhi syarat, terutama dari segi mutu, kesehatan, keselamatan, dan keyakinan agama. Realisasi instruksi tersebut diupayakan dengan peningkatan dan pengawasan kegiatan produksi, peredaran, dan atau pemasaran makanan olahan yang dilakukan secara terus-menerus dan terkoordinir. ${ }^{29}$

UU No. 23 Tahun 1992 yang telah disempurnakan dengan UU No. 36 Tahun 2009 memuat salah satu topik utama tentang pemberian kewenangan kepada Menkes untuk melakukan pengawasan dan penelitian makanan, baik dari segi kesehatan maupun kehalalannya.

Kepmenkes RI No. 82/Menkes/SK/I/1996 tentang Pencantuman Tulisan "Halal" pada Label Makanan, yang diubah dengan Kepmenkes RI No. 924/Menkes/SK/VIII/1996 tentang Perubahan atas Kepmenkes RI No. 82/Menkes/SK/1996, memuat ketentuan teknis pelaksanaan labelisasi yang didasarkan atas hasil sertifikasi halal. Label atau logo "Halal" dicantumkan jika makanan tidak mengandung unsur atau bahan yang terlarang atau haram, dan telah memperoleh sertifikat halal dari Majelis Ulama Indonesia (MUI) serta Surat Persetujuan Pencantuman Tulisan Halal pada Label dari Departemen Kesehatan (Depkes) yang sekarang telah berubah menjadi Badan Pengawas Obat dan Makanan (BPOM). Berdasarkan Pasal 10 dan 11 pada Kepmenkes No. 924 tersebut, Depkes, Depateman Agama (Depag), dan MUI bersepakat bahwa permintaan sertifikasi dan label halal dilakukan melalui satu pintu pemeriksaan yang dilakukan Tim Gabungan yang terdiri dari unsur ketiga pihak. Hasil pemeriksaan kemudian disidangkan oleh Tim Pakar MUI untuk selanjutnya dibahas dalam Komisi Fatwa MUI. Berdasarkan fatwa MUI yang dituangkan dalam sertifikat halal, Depkes memberikan izin pencantuman label halal atas produk yang bersangkutan.

UU No. 7 Tahun 1996 berkaitan dengan regulasi jaminan produk halal, antara lain: (1) menyatakan secara tegas bahwa produk luar dan dalam negeri wajib mencantumkan label pada, di

29 May Lim Charity, "Jaminan Produk Halal di Indonesia", Jurnal Legislasi Indonesia, Vol. 14, No. 1 (2017), 103. 
dalam, dan atau di kemasan pangan, dan label tersebut setidaknya mencantumkan keterangan halal; (2) benar-tidaknya status halal tersebut harus bisa dibuktikan menurut bahan baku, bahan tambahan, hingga proses pembuatannya, dan oleh karenanya label halal tidak bisa diberikan sendiri oleh produsen, tetapi mesti melalui serangkaian uji laboratorium (proses sertifikasi halal); (3) tidak mencantumkan secara spesifik pihak yang berhak memberikan sertifikat halal. Poin terakhir ini menimbulkan polemik antara MUI, Depkes, Depag, dan Departemen Perdagangan dan Industri. ${ }^{30}$

UU No. 8 Tahun 1999 tentang Perlindungan Konsumen menjelaskan bahwa perlindungan konsumen meliputi asas manfaat, keadilan, keseimbangan, keamanan dan keselamatan konsumen, serta kepastian hukum. Dalam hal ini, tertulis pada pasal 4, konsumen secara eksplisit berhak mendapatkan jaminan perlindungan hukum dari adanya UU tersebut. Sementara itu, pada Pasal 5 disebutkan bahwa kewajiban konsumen di antaranya: a) membaca atau mengikuti petunjuk informasi dan prosedur pemakaian atau pemanfaatan barang dan atau jasa demi keamanan dan keselamatan; b) beriktikad baik dalam melakukan transaksi pembelian barang dan atau jasa; c) membayar sesuai dengan nilai tukar yang disepakati; dan d) mengikuti upaya penyelesaian hukum sengketa perlindungan konsumen secara patut.

Penyampaian informasi yang berkaitan dengan produk makanan harus menyertakan jaminan kehalalannya. Hal tersebut penting terutama bagi kaum Muslim yang berpandangan bahwa mengkonsumsi produk halal merupakan ketentuan shari'ah yang tidak dapat ditawar. ${ }^{31}$

PP No. 69 Tahun 1999 tentang Label dan Iklan Pangan, Pasal 2 ayat (1) menyatakan bahwa pengaturan pencantuman keterangan halal pada label pangan diatur dalam pasal tersendiri, yaitu Pasal 10 dan Pasal 11. Pada Pasal 10 tersebut, tepatnya ayat (1), dijelaskan bahwa keterangan halal merupakan bagian yang tidak terpisahkan dari label. Pencantuman keterangan halal atau tulisan "halal" pada

30 UU No. 7 Tahun 1996 ini kemudian disempurnakan dengan UU No. 18 Tahun 2012 tentang Pangan.

31 Tulus Abadi et al., Tim Pengkajian Hukum tentang Peran Serta Masyarakat dalam Pemberian Informasi Halal (Jakarta: Kementerian Hukum dan Hak Asasi Manusia Badan Pembinaan Hukum Nasional, 2011), 22. 
label pangan merupakan kewajiban apabila pihak yang memproduksi dan atau memasukkan pangan ke dalam wilayah Indonesia menyatakan (mengklaim) bahwa produknya halal bagi umat Islam. Kebenaran suatu pernyataan kehalalan pangan tidak hanya dibuktikan dari segi bahan baku, bahan tambahan pangan, atau bahan bantu yang digunakan dalam memproduksi pangan, tetapi harus pula dapat dibuktikan dalam proses produksinya. Untuk mendukung kebenaran pernyataan halal, setiap pelaku usaha wajib memeriksakan terlebih dahulu produk pangannya pada lembaga pemeriksa yang telah diakreditasi sesuai dengan ketentuan peraturan perundang-undangan yang berlaku. ${ }^{32}$

Kepmenag No. 518 Tahun 2001 dan No. 519 Tahun 2001 menyatakan bahwa Menag menunjuk MUI sebagai lembaga pelaksana pemeriksaan kehalalan pangan. Pemeriksaan pangan ini meliputi (1) pemeriksaan atau verifikasi data pemohon; (2) pemeriksaan proses produksi; (3) pemeriksaan laboratorium; (4) pemeriksaan pengepakan, pengemasan, dan penyimpanan produk; (5) pemeriksaan sistem transportasi, distribusi, pemasaran, dan penyajian; dan (6) pemrosesan dan penetapan sertifikasi halal. ${ }^{33}$

Pengaturan tentang produk halal tidak secara eksplisit diatur oleh UU Kesehatan. Regulasi ini hanya memberikan rambu-rambu secara umum dalam memproduksi, mengolah, serta mendistribusikan makanan dan minuman hasil teknologi rekayasa genetik agar terjamin keamanannya bagi manusia, hewan yang bisa dimakan, dan lingkungan. ${ }^{34}$ Selain itu, setiap orang maupun badan hukum yang memproduksi dan mempromosikan produk makanan dan minuman atau yang diperlakukan sebagai makanan dan minuman hasil olahan teknologi dilarang menggunakan kata-kata mengecoh atau disertai klaim yang tidak dapat dibuktikan kebenarannya. Pengawasan terhadap penerapan sistem JPH yang dipersyaratkan menjadi tanggung jawab pemerintah pusat dan daerah. ${ }^{35}$

\footnotetext{
32 Ibid., 27.

33 Lihat Kepmenag No. 518 Tahun 2001 tentang Pedoman dan Tata Cara Pemeriksaan dan Penetapan Pangan Halal dan Kepmenag No. 519 Tahun 2001 tentang Lembaga Pelaksana Pemeriksaan Pangan Halal.

34 UU No. 18 Tahun 2009 tentang Peternakan dan Kesehatan Hewan.

35 UU No. 18 Tahun 2012 tentang Pangan, Pasal 95, menyatakan bahwa pemerintah pusat dan daerah melakukan pengawasan terhadap penerapan sistem jaminan produk halal bagi yang dipersyaratkan terhadap pangan.
} 
UU No. 18 Tahun 2012 tentang Pangan yang merupakan pengganti UU No. 7 Tahun 1996 menyebutkan dalam konsiderannya bahwa pangan merupakan kebutuhan dasar manusia yang paling utama, dan pemenuhannya merupakan bagian dari hak asasi manusia yang dijamin dalam UUD 1945, sebagai komponen dasar untuk mewujudkan sumber daya manusia yang berkualitas. Oleh karena itu, negara berkewajiban mewujudkan ketersediaan, keterjangkauan, dan pemenuhan konsumsi pangan yang cukup, aman, bermutu, dan bergizi seimbang.

Mengenai pelabelan halal, pelaku usaha pangan wajib mencantumkan label halal di dalam dan atau pada kemasan pangan. Hal ini berlaku baik untuk produsen domestik maupun produsen pangan impor yang memasuki wilayah Indonesia. Pencantuman label di dalam dan atau pada kemasan pangan ditampilkan dengan bahasa Indonesia secara tegas dan jelas sehingga mudah dimengerti oleh masyarakat. Dalam hal promosi atau iklan label halal sebuah produk pangan, produsen atau pelaku usaha harus benar-benar bisa mempertanggung-jawabkan kehalalan produk tersebut. ${ }^{36}$ Demikian pula, iklan yang menyebutkan kehalalan sebuah produk pangan, membuat setiap orang yang terkait bertanggung-jawab atas kebenarannya. ${ }^{37}$

UU No. 33 Tahun 2014 memperkuat dan mengatur berbagai regulasi halal yang selama ini tersebar di berbagai peraturan perundang-undangan. Pengaturannya pun menjangkau kehalalan produk dari hulu sampai hilir. ${ }^{38}$ Dengan adanya regulasi ini, sertifikasi halal menjadi bersifat mandatory (kewajiban), berubah dari keadaan sebelumnya yang bersifat voluntary (sukarela). Dengan demikian, semua produk yang masuk, beredar, dan diperdagangkan di wilayah Indonesia wajib bersertifikat halal. Hal ini tidak ditemukan pada produk perundang-undangan sebelumnya. Adapun tanggung jawab atas sistem jaminan halal dibebankan pada pemerintah, dalam hal ini adalah Menag, dengan membentuk BPJPH yang dibawahi oleh dan bertanggung-jawab kepada Menag. BPJPH bekerja sama dengan kementerian atau lembaga terkait, dalam hal ini Lembaga Pemeriksa Halal (LPH) dan MUI, untuk melaksanakan kewenangannya. Kerja sama BPJPH dengan LPH

\footnotetext{
36 UU No. 18 Tahun 2012 tentang Pangan, Pasal 97.

${ }^{37}$ UU No. 18 Tahun 2012 tentang Pangan, Pasal 105.

38 UU No. 33 Tahun 2014 tentang Jaminan Produk Halal, Pasal 1 ayat (1).
} 
dijalin untuk kepentingan pemeriksaan dan atau pengujian produk. Sementara kerja sama BPJPH dengan MUI dilakukan dalam bentuk sertifikasi auditor halal, penetapan kehalalan produk, dan akreditasi LPH. ${ }^{39}$

2. Mandatory (kewajiban) dan voluntary (sukarela) sertifikasi halal

Kategori mandatory untuk kegiatan sertifikasi produk halal ini termasuk sesuatu yang penting. Dengan adanya ikatan yang wajib, maka implikasi hukumnya adalah bahwa semua produk yang diperdagangkan di Indonesia wajib disertifikasi dan dilabeli halal. Sebelum UU No. 33 Tahun 2014 disahkan, pengaturan produk halal di Indonesia mengandung tiga norma sekaligus, yaitu: (1) voluntary; (2) mandatory bagi produk hewan; dan (3) mandatory if recommended (wajib jika dipersyaratkan).

3. Ketentuan pidana

Tidak ada penyebutan secara eksplisit tentang ketentuan pidana pada beberapa regulasi yang berkaitan dengan sertifikasi maupun labelisasi halal di Indonesia, mulai dari regulasi yang paling awal, SK Menkes No. 280/Menkes/Per/XI/1976 tentang Ketentuan Peredaran dan Penandaan pada Makanan yang Mengandung Bahan Berasal dari Babi, hingga yang paling mutakhir, UU No. 33 Tahun 2014 tentang Jaminan Produk Halal, kecuali hanya pada regulasi tertentu yang menyebutkan ketentuan pidana bagi yang melakukan pelanggaran dalam sertifikasi maupun labelisasi halal.

4. Lembaga pengelola atau penyelenggara jaminan produk halal

Lembaga pengelola sertifikasi dan labelisasi halal yang dimaksud di sini ini adalah sebuah badan atau lembaga yang diberi wewenang oleh suatu regulasi resmi untuk mengelola dan menyelenggarakan sertifikasi halal di Indonesia. Dalam kurun waktu hingga pengesahan UU No. 33 Tahun 2014, secara resmi belum ada lembaga yang diberi wewenang oleh regulasi setingkat UU sebagai pengelola dan penyelenggara sertifikasi halal di Indonesia. Namun demikian, pada 2001 Kementerian Agama (saat itu Depag) mengeluarkan sebuah regulasi berupa Kepmenag No. 519 tentang Lembaga Pelaksana Pemeriksaan Pangan Halal. Poin utama dalam regulasi tersebut adalah bahwa pemerintah (dalam hal ini Depag) menunjuk MUI sebagai lembaga pelaksana pemeriksaan kehalalan pangan yang dikemas untuk diperdagangkan di

${ }^{39}$ UU No. 33 Tahun 2014 tentang Jaminan Produk Halal, Pasal 10. 
Indonesia, ${ }^{40}$ yang teknis pelaksanaannya telah dirinci pada pembahasan sebelumnya.

Depag dengan LPPOM MUI dan BPOM melakukan kerjasama dalam menangani sertifikasi dan labelisasi halal di Indonesia. ${ }^{41}$ Model sertifikasi seperti ini berjalan sukses sampai munculnya UU JPH pada 2014. Pemberian akses oleh Depag kepada MUI lewat LPPOM-nya untuk melaksanakan sertifikasi halal menjadikan MUI sebagai satu-satunya lembaga keagamaaan yang menangani kegiatan sertifikasi halal.

Pengesahan UU JPH pada masa Presiden Susilo Bambang Yudhoyono ini memberikan beberapa perbedaan pengelolaan sertifikasi halal. Salah satunya adalah dari sisi lembaga pengelola sertifikasi yang awalnya berada di bawah kewenangan LPPOM MUI berubah menjadi kewenangan BPJPH. $^{42}$ Perubahan ini merupakan sebuah ikhtiar untuk membuat penyelenggaraan sertifikasi halal di Indonesia semakin baik.

\section{Regulasi Penyelenggaraan Jaminan Produk Halal Perspektif Statute Approach}

Tiga asas hukum yang dikembangkan oleh Marzuki, yaitu asas lex superior derogat legi inferiori, asas lex specialis derogat legi generali, dan asas lex posterior derogat legi priori, pada bagian ini akan digunakan untuk melihat dan mengenalisis peraturan perundang-undangan jaminan produk halal di Indonesia, sejak pertama kali dibuat pada masa Orba hingga kini. Dengan demikian, perbandingan antara satu peraturan dengan peraturan lainnya terkait jaminan produk halal menjadi tidak terelakkan, sehingga perkembangan regulasi terkait hal tersebut akan dapat tergambarkan dengan baik.

Berdasarkan asas lex superior derogat legi inferiori (aturan hukum yang lebih tinggi mengganti aturan hukum yang lebih rendah),

\footnotetext{
40 Kepmenag No. 519. Tahun 2001 tentang Lembaga Pelaksana Pemeriksaan Pangan Halal, Pasal 1.

${ }^{41}$ Kepmenag No. 519 Tahun 2001 tentang Lembaga Pelaksana Pemeriksaan Pangan Halal, Pasal 3 berbunyai: "Ketentuan lebih lanjut mengenai pelaksanaan kegiatan sebagaimana dimaksud dalam Pasal 2, diatur oleh Menteri Agama Republik Indonesia dan Majelis Ulama Indonesia, baik secara sendiri-sendiri maupun bersama-sama".

42 UU No. 33 Tahun 2014 tentang Jaminan Produk Halal, Pasal 1 ayat 6 berbunyi: "Badan Penyelenggara Jaminan Produk Halal yang selanjutnya disingkat BPJPH adalah badan yang dibentuk oleh pemerintah untuk menyelenggarakan JPH.
} 
maka segala aturan penyelenggaraan jaminan produk halal yang memiliki posisi tinggi harus menggantikan segala aturan penyelenggaraan jaminan produk halal yang lebih rendah. Asas ini dapat digunakan untuk melihat subtansi, isi, dan aturan penyelenggaraan jaminan produk halal yang tercantum dalam (1) SK Menkes No. 280/Menkes/Per/XI/1976 tanggal 10 November 1976 tentang Ketentuan Peredaran dan Penandaan pada Makanan yang Mengandung Bahan Berasal dari Babi; (2) SKB Menkes dan Menag No. 427/Menkes/SKB/VIII/1985 dan No. 68 Tahun 1985 tentang Pencantuman Tulisan "Halal" pada Label Makanan; (3) Inpres No. 2 Tahun 1991 tentang Peningkatan Pembinaan dan Pengawasan Produksi dan Peredaran Makanan Olahan; (4) Kepmenkes RI No. 82/Menkes/SK/I/1996 tentang Pencantuman tulisan "Halal" pada Label Makanan, yang diubah dengan Kepmenkes RI No. 924/Menkes/SK/VIII/1996; (5) Kepemenag No. 518 Tahun 2001 tentang Pedoman dan Tata Cara Pemeriksaan dan Penetapan Pangan Halal dan Kepmenag No. 519 Tahun 2001 tentang Lembaga Pelaksana Pemeriksaan Pangan Halal; dan (6) PP No. 69 Tahun 1999 tentang Label dan Iklan Pangan, yang semua itu diganti oleh regulasi penyelenggaraan jaminan produk halal yang memiliki posisi tinggi, yaitu: 1) UU No. 23 Tahun 1992 tentang Kesehatan; 2) UU No. 7 Tahun 1996 tentang Pangan; 3) UU No. 8 Tahun 1999 tentang Perlindungan Konsumen; 4) UU No. 18 Tahun 2009 tentang Peternakan dan Kesehatan Hewan; 5) UU No. 18 tahun 2012 tentang Pangan; dan 6) UU No. 33 Tahun 2014 tentang Jaminan Produk Halal.

Sementara itu, menurut asas lex specialis derogat legi generali (aturan hukum yang khusus mengganti aturan hukum yang lebih umum), aturan penyelenggaraan jaminan produk halal yang khusus menggantikan aturan yang umum. Jika asas ini diterapkan dalam konteks UU, maka UU No. 33 Tahun 2014 tentang JPH merupakan regulasi khusus yang mengatur penyelenggaraan jaminan produk halal di Indonesia. UU No. 33 tersebut menggantikan aturan-aturan penyelenggaraan jaminan produk halal sebelumnya, misalnya: 1) UU No. 23 Tahun 1992 tentang Kesehatan; 2) UU No. 7 Tahun 1996 tentang Pangan; 3) UU No. 8 Tahun 1999 tentang Perlindungan Konsumen; 4) UU No. 18 Tahun 2009 tentang Peternakan dan Kesehatan Hewan; dan 5) UU No. 18 Tahun 2012 tentang Pangan. 
Kelima UU yang disebutkan terakhir tersebut tergantikan oleh UU JPH yang notabene sebagai regulasi khusus yang berkaitan dengan penyelenggaraan jaminan produk halal. Selain itu, aturanaturan penyelenggaraan jaminan produk halal yang sebetulnya berstatus di bawah UU, seperti (1) SK Menkes No. 280/Menkes/Per/XI/1976 tanggal 10 November 1976 tentang Ketentuan Peredaran dan Penandaan pada Makanan yang Mengandung Bahan Berasal dari Babi; (2) SKB Menkes dan Menag No. 427/Menkes/SKB/VIII/1985 dan No. 68 Tahun 1985 tentang Pencantuman Tulisan "Halal" pada Label Makanan; (3) Inpres No. 2 Tahun 1991 tentang Peningkatan Pembinaan dan Pengawasan Produksi dan Peredaran Makanan Olahan; (4) Kepmenkes RI No. 82/Menkes/SK/I/1996 tentang Pencantuman Tulisan "Halal" pada Label Makanan, yang diubah dengan Kepmenkes RI No. 924/Menkes/SK/VIII/1996; (5) Kepmenag No. 518 Tahun 2001 tentang Pedoman dan Tata Cara Pemeriksaan dan Penetapan Pangan Halal dan Kepmenag No. 519 Tahun 2001 tentang Lembaga Pelaksana Pemeriksaan Pangan Halal; dan (6) Permen No. 69 Tahun 1999 tentang Label dan Iklan Pangan, secara otomatis dinyatakan tidak berlaku.

Kemudian berdasarkan asas hukum yang terakhir, lex posterior derogat legi priori (aturan hukum yang baru menggantikan aturan hukum yang lebih lama), aturan penyelenggaraan jaminan produk halal yang termaktub dalam UU JPH menggantikan aturan penyelenggaraan jaminan produk halal yang ada pada periode sebelumnya, seperti: 1) UU No. 23 Tahun 1992 tentang Kesehatan; 2) UU No. 7 Tahun 1996 tentang Pangan; 3) UU No. 8 Tahun 1999 tentang Perlindungan Konsumen; 4) UU No. 18 Tahun 2009 tentang Peternakan dan Kesehatan Hewan; dan 5) UU No. 18 Tahun 2012 tentang Pangan, serta peranturan-peraturan lain yang statusnya lebih rendah dari kelima regulasi yang berbentuk UU tersebut.

\section{Penutup}

Dari pembahasan yang telah dilakukan, dapat ditarik beberapa kesimpulan. Pertama, terdapat beberapa isu dan topik krusial yang berkaitan dengan penyelenggaraan jaminan produk halal di Indonesia, yaitu (1) sertifikasi atau labelisasi halal; (2) kategori mandatory (kewajiban) dan valountary (sukarela) dalam sertifikasi 
halal; (3) ketentuan pidana; dan (4) lembaga pengelola jaminan produk halal.

Kedua, regulasi penyelenggaraan jaminan produk halal di Indonesia ketika ditinjau dari statute approach dapat dianalisis dengan tiga asas hukum. Pertama, asas Lex Superior Derogat Legi Inferiori menyimpulkan bahwa segala aturan jaminan produk halal yang memiliki posisi tinggi harus menggantikan segala aturan jaminan produk halal yang lebih rendah. Dengan demikian, aturan jaminan produk halal yang tercantum dalam 1) UU No. 23 Tahun 1992 tentang Kesehatan; 2) UU. No. 7 Tahun 1996 tentang Pangan; 3) UU No. 8 Tahun 1999 tentang Perlindungan Konsumen; 4) UU No. 18 Tahun 2009 tentang Peternakan dan Kesehatan Hewan; dan 5) UU No. 18 Tahun 2012 tentang Pangan, yang kemudian dikuatkan oleh UU JPH harus diutamakan ketimbang aturanaturan di bawahnya. Kedua, asas Lex Specialis Derogat Legi Generali menegaskan bahwa UU JPH merupakan regulasi khusus atau spesifik yang mengatur jaminan produk halal. UU JPH ini menggantikan aturan-aturan jaminan produk halal sebelumnya yang bersifat umum, misalnya 1) UU No. 23 Tahun 1992 tentang Kesehatan; 2) UU No. 7 Tahun 1996 tentang Pangan; 3) UU No. 8 Tahun 1999 tentang Perlindungan Konsumen; 4) UU No. 18 Tahun 2009 tentang Peternakan dan Kesehatan Hewan; dan 5) UU No. 18 Tahun 2012 tentang Pangan, yang salah satu isinya menyebutkan bahwa sertifikasi halal boleh bersifat sukarela dan lain-lain. Ketiga, asas Lex Posterior Derogat Legi Priori meniscayakan aturan jaminan produk halal yang termaktub dalam UU JPH menggantikan aturan jaminan produk halal yang ada pada periode sebelumnya, seperti 1) UU No. 23 Tahun 1992 tentang Kesehatan; 2) UU No. 7 Tahun 1996 tentang Pangan; 3) UU No. 8 Tahun 1999 tentang Perlindungan Konsumen; 4) UU No. 18 Tahun 2009 tentang Peternakan dan Kesehatan Hewan; dan 5) UU No. 18 Tahun 2012 tentang Pangan.

\section{Daftar Rujukan}

\section{Buku dan Jurnal}

Abadi, Tulus et al. Tim Pengkajian Hukum tentang Peran Serta Masyarakat dalam Pemberian Informasi Halal Jakarta: Kementerian Hukum dan Hak Asasi Manusia Badan Pembinaan Hukum Nasional, 2011), 22. 
Adam, Panji. "Kedudukan Sertifikasi Halal dalam Sistem Hukum Nasional sebagai Upaya Perlindungan Konsumen dalam Hukum Islam", Jurnal Amwaluna, Vol. 1, No. 1, 2017.

Charity, May Lim. "Jaminan Produk Halal di Indonesia", Jurnal Legislasi Indonesia, Vol. 14, No. 1, 2017.

Detik.com. "RUU Jaminan Halal Ditarget Selesai dibabas Februari 2013”, 23 Januari 2013, https://news.detik.com/berita/ 2150155/ruu-jaminan-produk-halal-ditarget-selesai-dibahasfebruari-2013. Diakses 10 Mei 2019.

Faidah, Mutimmatul. "Sertifikasi Halal di Indonesia; Dari Civil Society Menuju Relasi Kuasa Antara Negara dan Agama", Islamica: Jurnal Studi Keislaman, Vol. 11, No. 2, 2017.

Ghofur, Abdul. "Pergumulan Politik Legislasi Undang-Undang Nomor 21 Tahun 2018 tentang Perbankan Syariah". Disertasi-IAIN Walisongo Semarang, 2013.

Ginting, Nembah F. Hartimbul. Manajemen Pemasaran. Bandung: Yrama Widya, 2011.

Hasan, KN Sofyan. "Kepastian Hukum Sertfikisai dan Labelisasi Halal Produk Pangan”, Jurnal Dinamika Hukum, Vol. 14, No. 2, 2014.

Hasan, KN Sofyan. Sertifikasi Halal dalam Hukum Positif: Regulasi dan Implementasinya di Indonesia. Yogyakarta: Aswaja Pressindo, 2014.

Hidayat, Asep Syarifuddin dan Mustolih Siradj. "Sertifikasi Halal dan Sertifikasi Non Halal pada Produk Pangan Industri", Abkam: Jurnal Ilmu Syariah, Vol. 15, No. 2, 2015.

Ibrahim, Johni. Teori \& Metodologi Penelitian Hukum Normatif. Malang: Banyumedia Publishing, 2006.

Isnaeni, Hendri F. "Sejarah Awal Label Halal”, 14 October 2016, dalam https://historia.id/agama/articles/sejarah-awal-labelhalal-PNRMZ. Diakses pada 24 Oktober 2018.

Jahar, Asep Saepudin dan Thalhah. "Dinamika Sosial Politik Pembentukan Undang-Undang Jaminan Produk Halal", AlIbkam: Jurnal Hukum dan Pranata Sosial, Vol. 12, No. 2, 2017.

Kompas.com. "Debat Sengit RUU Produk Halal terkait Siapa yang Harus Menangani Sertifikasi”, 27 Februari 2014. Diakses pada 25 April 2019.

Marzuki, Peter Mahmud. Penelitian Hukum. Jakarta: Prenada Media Group, 2010. 
Purnamasari, Teti Indrawati. "Pengaturan Bentuk-Bentuk Perlindungan Konsumen dalam Penyelenggaraan Jaminan Produk Halal dan Tayib di Indonesia". Disertasi--Universitas Gadjah Mada Yogyakarta, 2015.

-----. "Sertifikasi dan Labelisasi Produk Pangan Halal dalam Rangka Perlindungan Konsumen Muslim di Indonesia”, Jurnal Istinbath, Vol. 1, No. 1, 2005.

Ramlan dan Nahrowi. "Sertifikasi Halal sebagai Penerapan Etika

Bisnis Islami dalam Upaya Perlindungan bagi Konsumen Muslim”, Abkam: Jurnal Ilmu Syariah, Vol. 14, No. 1, 2014.

Siradjuddin, Azmi. "Regulasi Makanan Halal di Indonesia", Jurnal Tapis, Vol. 13, No. 01, 2013.

Soekanto, Soerjono et al. Penelitian Hukum Normatif: Suatu Tinjanan Singkat. Jakarta: Rajawali, 2006.

Soemitro, Ronny Hanitijo. Metodologi Penelitian Hukum dan Jurimetri. Jakarta: Ghalia Indonesia, 1988.

Sumadi. Metode Penelitian. Jakarta: Rajawali 1988.

\section{UU dan Peraturan Sejenisnya}

Instruksi Presiden Nomor 2 Tahun 1991 tentang Peningkatan

Pembinaan dan Pengawasan Produksi dan Peredaran Makanan Olahan.

Keputusan Bersama Menteri Kesehatan dan Menteri Agama RI No.427/Menkes/VIII/1985 dan No. 68 tahun 1985 Tentang Pencantuman Tulisan "Halal" Pada Lebel Makanan.

Keputusan Menteri Agama No. 519. Tahun 2001 tentang Lembaga Pelaksana Pemeriksaan Pangan Halal.

Keputusan Menteri Agama No.518 Tahun 2001 tentang Pedoman dan tata cara pemeriksaan dan Penetapan Pangan Halal.

Peraturan Menteri Kesehatan RI No. 76/Menkes/Per/III/78 tentang Label dan Periklanan Makanan.

Peraturan Pemerintah Nomor 69 Tahun 1999 tentang Label dan Iklan Pangan.

Surat Keputusan Bersama Menteri Agama dan Menteri Kesehatan No. 472/Menkes/SKB/VIII/1985 dan No. 68/1985 tentang Pengaturan Tulisan "Halal" pada Label Makanan.

Surat Keputusan Bersama Menteri Agama dan Menteri Kesehatan No. 472/Menkes/SKB/VIII/1985 dan No. 68/1985 tentang Pengaturan Tulisan "Halal" pada Label Makanan. 
Surat Keputusan Menteri Kesehatan No. 280/Men.Kes/Per/XI/1976 tanggal 10 November 1976 tentang Ketentuan Peredaran dan Penandaan pada Makanan yang Mengandung Bahan Berasal dari Babi.

Surat Keputusan Menteri Pertanian No. 555/Kpts/TN.240/9/1986 tentang Syarat-syarat Rumah Pemotongan Hewan dan Usaha Pemotongan Hewan.

Surat Keputusan Menteri Pertanian No.557/Kpts/TN520/9/1987 tentang Syarat-Syarat Rumah Pemotongan Hewan Unggas dan Usaha Pemotongan Unggas.

Undang-Undang Nomor 10 Tahun 2004 tentang Pemebntukan Peraturan Per-Undang-Undangan.

Undang-Undang Nomor 18 Tahun 2009 tentang Peternakan dan Kesehatan Hewan.

Undang-Undang Nomor 18 Tahun 2012 tentang Pangan.

Undang-Undang Nomor 23 Tahun 1992 tentang Kesehatan.

Undang-Undang Nomor 23 Tahun 1992 tentang Kesehatan.

Undang-Undang Nomor 33 Tahun 2014 tentang Jaminan Produk Halal.

Undang-Undang Nomor 36 Tahun 2009 tentang Kesehatan.

Undang-Undang Nomor 7 Tahun 1996 tentang Pangan.

Undang-Undang Nomor 8 Tahun 1999 tentang Perlindungan Konsumen. 